\title{
Bilateral breast cancer in a Nigerian community
}

\author{
Wilson I. B. Onuigbo* \\ Department of Pathology, Medical Foundation and Clinic, 8 Nsukka Lane, Enugu Nigeria
}

\begin{abstract}
In different parts of the world, there is published evidence regarding the bilateral synchronous occurrence of breast cancer. Therefore, this paper considers the parameters met among the Igbo Ethnic Group, who are domiciled mostly in South-Eastern Nigeria. The median age was 42 years. In the series of 6 cases, all but one was synchronous. The histological type tended to be the same on both sides, including one woman in whom three distinct types occurred bilaterally. Ductal carcinoma was the commonest type while the odd inflammatory carcinoma was prominent.
\end{abstract}

\section{Introduction}

Bilateral breast cancer has been reported from countries as diverse as USA, Italy, Greece, India, and Japan [1-5]. Therefore, the present paper documents the parameters discovered among the Igbo Ethnic Group, which is domiciled in South-Eastern Nigeria. The work was facilitated by following the advice of a Birmingham (UK) group to the effect that having a histopathology data pool encourages epidemiological analysis [6,7].

\section{Investigation}

Such a pool in Enugu enabled the author to document cases of bilateral breast cancer in this developing community. In particular, the doctors were encouraged to submit biopsies with relevant clinical notes.

\section{Discussion}

Greek authors documented a large series of bilateral breast cancer, concluding that the histopathologic type of the one tumor was the same as the other in $62.8 \%$ of all cases [8]. The proportion was $83.3 \%$ locally. As regards the median age, Indian authors obtained 40 years, while a Korean group got 41 years, and a Chinese case was 43 years old [9-11]. The present cohort came to the close 42.5 years.

A combined team of Swedish and US investigators lamented that "Little is known, however, about incidence trends and prognostic features of bilateral breast cancer" [12]. What does the present series add? It is striking that inflammatory carcinoma, which is uncommon, cropped up here rather often. No doubt, such epidemiological parameters merit documentation [13].

Table 1. Epidemiological data on bilateral breast cancer

\begin{tabular}{|c|c|c|c|c|c|}
\hline No & Initials & Age & Right & Left & Onset \\
\hline 1 & US & 45 & If & If & Synchronous \\
\hline 2 & IT & 40 & If & If & Synchronous \\
\hline 3 & EL & 36 & $\mathrm{Mu}, \mathrm{Du}$ & $\mathrm{Du}$ & Synchronous \\
\hline 4 & EO & 43 & $\mathrm{Du}$ & $\mathrm{Du}$ & Synchronous \\
\hline 5 & IN & 35 & $\mathrm{Du}$ & $\mathrm{Du}$ & Metachronous \\
\hline 6 & UL & 52 & If, Du, Lo & If, Du, Lo & Synchronous \\
\hline
\end{tabular}

If: Inflammatory carcinoma; Du: Ductal carcinoma; Mu: Mucinous carcinoma; Lo: Lobular carcinoma

Copyright: (C2017 Onuigbo WIB. This is an open-access article distributed under the terms of the Creative Commons Attribution License, which permits unrestricted use, distribution, and reproduction in any medium, provided the original author and source are credited.

\section{References}

1. Safal M, Lower EE, Hasselgren PO, Hungness ES, Gazder P, et al. (2002) Bilateral synchronous breast cancer and her-2/neuexprexpression. Breast Cancer Res Treat 72 : 195-201. [Crossref]

2. Intra M, Rotmensz N, Viale G, Mariani L, Bonanni B, et al. (2004) Clinicopathologic characteristics of 143 patients with synchronous bilateral invasive breast carcinomas treated in a single institution. Cancer 101: 905-912.[Crossref]

3. Zagouri F, Sergentanis TN, Koulocheri D, Nonni A, Bousiotou A, et al. (2007) Bilateral synchronous breast carcinomas followed by a metastasis to the gallbladder: A case report. World J SurgOncol 5: 101.

4. Chandrika, Permi HS, Prasad HLK, et al. (2012) Synchronous bilateralmedullary carcinoma of breast: Is it metastasis or second primary? J Cancer Res Therap 8: 129131. [Crossref]

5. Hayashi M, Yamamoto Y, Takata N, Iwase H (2013) A case of synchronous bilateral breast cancer with different pathological responses to neoadjuvant chemotherapy with different biological character. Springerplus 2: 272.[Crossref]

6. Basden GT (1966) Niger Ibos. Cass, London.[Crossref]

7. Macartney JC, Rollaston TP, Codling BW (1980) Use of a histopathology data pool for epidemiological analysis. J ClinPathol 33: 351-353.[Crossref]

8. Gogas J, Markopoulos C, Skandalakis P, Gogas H (1993) Bilateral breast cancer. Am Surg 59: 733-735.

9. Lakshmaiah KC, Das U, Babu KG, Suresh TM, LokanathaD, et al. (2014) Clinicopathological profile of bilateral breast cancer at a tertiary cancer center in South India. Memo Magazine Euro Med Oncol 7: 157-161.

10. Gong SJ, Rha SY, Jeung HC, Roh JK, Yang WI, et al. (2007) Bilateral breast cancer: Differential diagnosis using histological and biological parameters. Jap J ClinOncol 37: 487-492.[Crossref]

11. ZhaoY, YuanN,Li K,GengY, ZhouH, et al. (2015) Bilateral breast cancer following augmentation mammaplasy with polyacrylamide hydrogel injection: A case report. Oncol Lett 9: 2687-2693.[Crossref]

12. Hartman M, Czene K, Reilly M, Adolfsson J, Bergh J, et al. (2007) Incidence and prognosis of synchronous and metachronous bilateral breast cancer. J ClinOncol25: 4210-4216.[Crossref]

13. Kramer A, Buzdar AU. Inflammatory breast carcinoma. Am J ClinOncol(CCT) 9 : 541-543.

Correspondence to: Wilson I. B. Onuigbo, Department of Pathology, Medical Foundation and Clinic, 8 Nsukka Lane, Enugu Nigeria, E-mail: wilson. onuigbo@gmail.com

Key words: breast, cancer, bilaterality, type, Igbos

Received: May 20, 2017; Accepted: June 17, 2017; Published: June 20, 2017 